〔74〕ポリカーボネートの溶融時における分子量および

分子量分布の変化について

(1963 年 12 月 18 日受理)

大江 武*・甲田広行* ・ 山崎博章*

\begin{abstract}
要 旨 通常のホスゲン化法によって合成されたポリカーボネート粉末を乾燥して, 窒素気流中で, 種 々な温度・時間溶融し，その分子量㧍よび分子量分布の変化を調へた。その結果， $320^{\circ} \mathrm{C}$ 以下の温度において は，分子量がある一定值まで低下すると，それ以上の低下がないこと，重量减がほとんどないこと，分子量分 布が鋭くなることを認めた。この現象は，低分子画分の多少，末反応モノマーの有無に著しく影幚されること から, 分子末端の水酸基によるエステル交換反応の動的平衡, すなわち, 分子分布の再配列に基くものであ るとの結論に達した。その際, 低分子側成分の若干の增加を認めた。
\end{abstract}

\section{1. 緒言}

ポリカーボネートの熱分解に関する報告は数多くなさ れている1”。こらの報告によると $300^{\circ} \mathrm{C}$ 以下では実質 的に，主鎖切断が起こっていないとされている。これに もかかわらず，実際の成形工程においては，分子量の低 下が認められる。この現象に関して, Yakubovich ${ }^{2)}$ は 分子量分布の再配列に基くものであること、その際，低 分子画分が著しく減少することを認めている。われわれ のこれまでの経験による上，低分子側成分の诚少を認め がたい。

本報では，ポリカーボネートの熱分解域以下の温度に おける分子量低下，お上び分子量分布の変化を調べ，そ の原因についての検討を行なった。

\section{2. 実験}

\section{1 試 料}

通常のホスゲン化法によって合成された重合粉木の中 から, 溶融による分子量低下の大きい試料 A（分子量= $\left.3.1 \times 10^{4}\right)$ と $\mathrm{B}\left(\right.$ 分子量 $\left.=2.9 \times 10^{4}\right)$ および，分子量低下

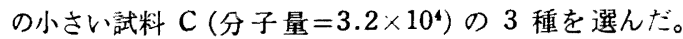
いずれも粒度は 10〜20メッシニの間にそろえた。

\section{2 試料の溶融}

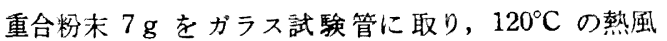
乾燥器で十分に乾燥した後, 同温度でピロガロール, 塭 化カルシウム乾燥管を通した空素気流で約 30 分, 空気 との置換老行なう。恒温槽は $\mathrm{NaNO}_{2}-\mathrm{KNO}_{3}$ 混合物 (融 点約 $\left.170^{\circ} \mathrm{C}\right)$ を浴とし, 通常の温度制御装置を付したも ので, 温度の制御精度は $\pm 2{ }^{\circ} \mathrm{C}$ 以下である。溶融は窒素 気流下で行なった。

溶融による重量減測定は, 試験管高含めた重量を溶融 の前後に測定し，その差から求めた。

* 三菱江戸川化学株式会社大阪工場 (大阪府豊中市神州町 2 番 12 号)

\section{3 分子量の測定}

\subsection{1 粘度法}

オストワルド型の粘度計にて, 温度 $20^{\circ} \mathrm{C}$, 濃度 2 点 ないし 4 点で,メチレンクロライド溶液の比粘度を測定 し，そのプロットから $\left[\gamma_{]}\right]$を求めた。 $\left[\gamma_{i}\right]$ から分子量を 求めるのは Schnell の式 ${ }^{3)}$

$$
[r]=1.23 \times 10^{-4} M^{0.83}
$$

によった。

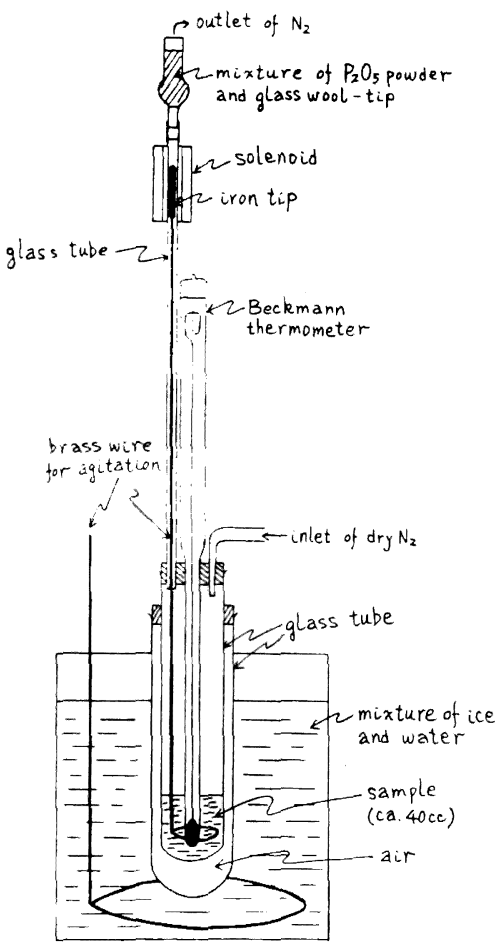

Fig. 1. Apparatus for measurement of freezing point depression. 


\section{3 .2 水点降下法}

ジオキサン溶液の氷点降下度を測定することにより, 低分子画分の数平均分子量を求めた。装置は Fig. 1 に 示した。この装㯰に扔いて， $\mathrm{P}_{2} \mathrm{O}_{5}$-ガラスウール充てん 管を通した窒素気流を通じることによって，7〜8 時間， 純浴媒の水点降下がなかったので, 窒素の乾燥は十分で ある。

ジオキサンは濃塩酸と惹沸した後, $\mathrm{KOH}$ で中和・脱 水し, さらに金属ナトリウムで乾燥した後, 蒸留・再結 晶し，金属ナトリウムとともに 1 週間放置したものを， 使用の直前に必要是だけ, 金属ナトリウム共存下に致留 した。

測定時の椧却速度は $0.2^{\circ} \mathrm{C} / \mathrm{min}$ (泠煤の温度 $7 \sim 8^{\circ} \mathrm{C}$ ) とした。温度はベックマン温度㖕で, $1 / 1000^{\circ} \mathrm{C}$ まで読 んだ。

水点の降下度 $(J T)$ 加分子量 $(M)$ を求めるには

$$
M=\frac{K_{f}}{\left(\begin{array}{c}
\lrcorner T \\
C
\end{array}\right)_{C=0}}
$$

によった。ここで， $K_{f}=4.95$ を使用した。本装置によ るp-ジクロルベンゼン（分子量＝147）の分子量測定結 果は 151 であった。

\section{4 分子量分布の测定}

\section{4 .1 低分子側分布の測定}

䄪 5\% メチレンクロライド溶液を水平なガラス板に 流展してつくった透明フィルム(厚み $=0.08 \mathrm{~mm}) 4 \mathrm{~g}$ を $1 \mathrm{~cm}^{2}$ 程度に切り, $100 \mathrm{cc}$ 三角フラスコに入れ, $23^{\circ} \mathrm{C}$ で約 20 時間, $50 \mathrm{cc}$ の抽出溶媒で処理し, 傾斜で液を 分濩・蒸発乾固して, 抽出量を測定した。抽出溶媒はア セトン, ベンゼン, ベンゼン上クロロホルムの混合比 (体積比) $44: 56,42: 58,40: 60,38: 62$ の順に用いた。 1 画分の抽出量は供試料の約 $2 \sim 3 \mathrm{wt} \%$ て，抽出照合 計はほほ $15 \mathrm{wt} \%$ であった。

各試料の抽出量は，標淮サンプルの同時処理によって 得られた抽出量を 100 として, 相対值で表わした。各 画分の相対值と各画分を合計したものの相対值とは平行 的な関倸にあったので実際には，各画分を合計した相対 组のみを用いた。

\section{4 .2 全分布曲線の测定}

約 $15 \%$ メチレンクロライド溶液を舟型ギーサーで， 水平なガラス板上に均一に流展し，ただちに $40 \sim 42^{\circ} \mathrm{C}$ の恒温槽に移し, 約 15 分で大部分のメチレンクロライ ドを蒸発させ、フィルムをガラス板からはがして, $70^{\circ} \mathrm{C}$, 5 時間, つついて $120^{\circ} \mathrm{C}, 24$ 時間乾燥して, 厚及 $0.06 \sim$ $0.08 \mathrm{~mm}, 20 \times 30 \mathrm{~cm}^{2}$ の透明なフィルムをつくる。

フィルム $50 \mathrm{~g}$ を約 $3 \mathrm{~cm}$ 四方に切り, $2 l$ 三角フラ
スコに入れて，アセトンーメチレンクロライド混合液で, 逐次溶解を行なう。溶媒の量は $1 l$, 温度 $23^{\circ} \mathrm{C}$, 抽出時 間 20 時間, 液の分離は 2 号ガラスフィルターによる自 然口過で行なった。本法による分別は, 分子量 $5.0 \times 10^{4}$ 以上の場合には困難であった。また，本報測定結果にお いても, 高分子側最後の 1 画分は, 相当分布の幅の広、 画分であろらと思われる。

\section{3. 結果}

\section{1 分子量の測定結果}

\subsection{1 粘度法}

粘度の測定結果は Fig. 2 に示した。八ギンスの定数

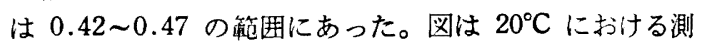
定結果であるが, $25^{\circ} \mathrm{C} の$ 測定結果も同様のハギンス定 数を示し, しかも, 文献) に報告されている結果とは異 なって，極限粘度も同一の値を示した。

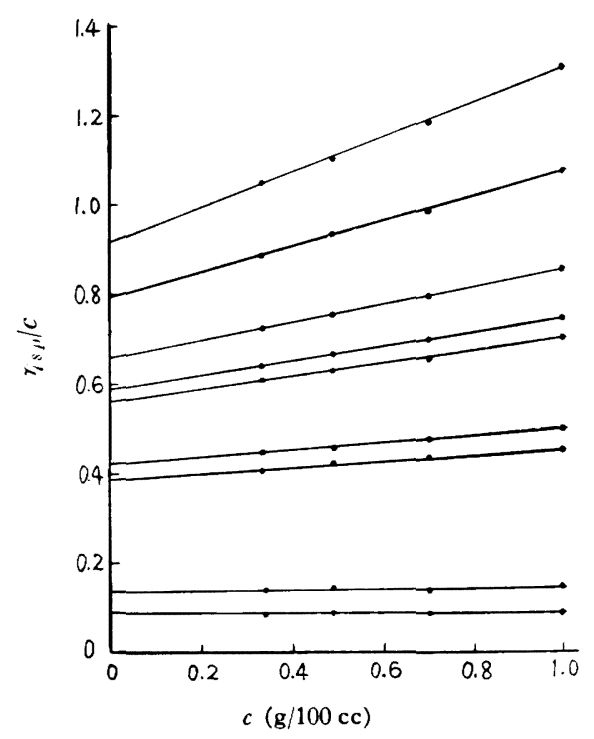

Fig. 2. Reduced viscosity at $20^{\circ} \mathrm{C}$ in methylenechloride versus concentration for a series of polycarbonate fractions.

\section{1 .2 水点降下法}

本測定系において, JT/C-C プロットは, 濃度に対し て負の勾配を示した。数平均分子量と $[\eta]$ との関保は Fig. 3 に示した。図中，点線は Schnell の式吾を低分 子側に延長したものである。また $\Delta$ 印はクロルベンゼ ンの沸点上昇法による結果 ${ }^{5)}$ である。 図の直線は

$$
\left[r_{6}\right]=1.33 \times 10^{-4} M^{0.96}
$$

なる関係を満たしている。 


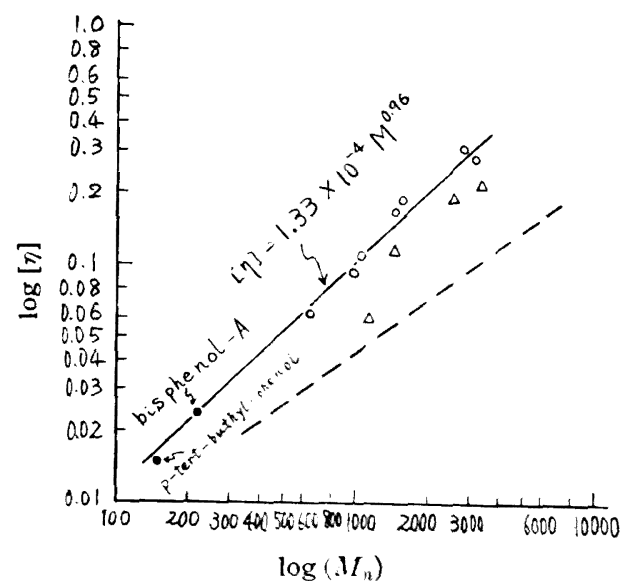

$\triangle$ : By boiling point elevation method ${ }^{3)}$

-.: Schnell's equation ${ }^{3)}$

- Monomer and terminater of polycarbonate

Fig. 3. Intrinsic viscosity at $20^{\circ} \mathrm{C}$ in methylenechloride plotted logarithmically against number average molecular weight determined by freezing point depression method in 1,4-dioxane.

分子量 657 のポリマーは, 常温でアセトンに浴出してく る成分で, $120^{\circ} \mathrm{C}$ で軟化， $140^{\circ} \mathrm{C}$ で完全に融解寸る。こ のような極低分子の含量は，1２ wto\% だあったが，溶 融法でつくられたもの(マンコロン)にはさらに多く含ま れていた。

\section{2 溶融による乌子量低下}

\section{2 .1 重合粉末の分子量低下および重量減}

試料 A およびC の话堅による分子量低下を Fig. 4, 5 にそれぞれ示した。层から，分子量の低下の大きい， 小さいにかかわらず， $320^{\circ} \mathrm{C}$ 以下の温度では，溶䗝温度

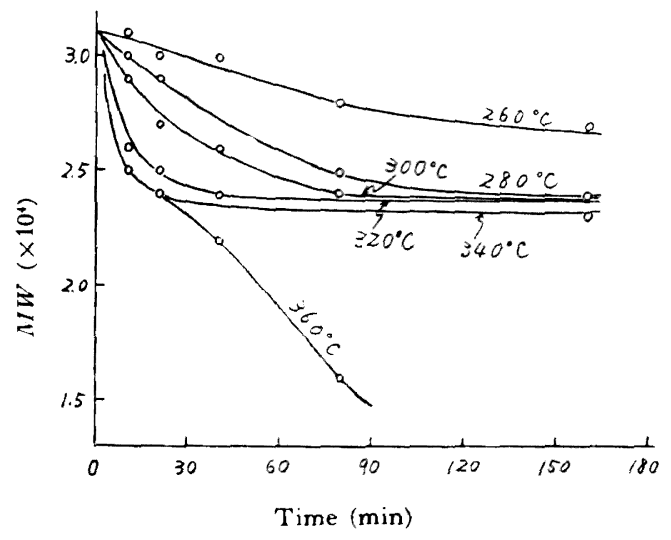

Sample: A, dried powder

Condition: Molten in $\mathbf{N}_{2}$ atmosphere

Fig. 4. Molecular weight after treatment at various temperatures.

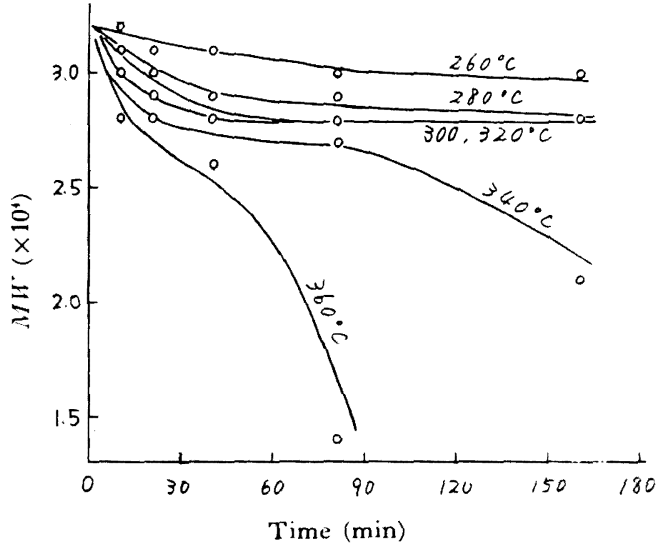

Sample: C, dried powder

Condition: Molten in $\mathrm{N}_{2}$ atmosphere

Fig. 5. Molecular weight after treatment at various temperatures.

によらず，分子量の低下がある一定值を有していること がわかる。浴融温度が低い場合は, 一定值士で低下する に要する時間が長くなる。300〜320 C において数時間 溶融した試料には，少量のメチレンクロライド不谪分が 見られた。

試料 Cによる溶融時の重量減を Table 1 に示した。 同じ試料を $170^{\circ} \mathrm{C}, 10$ 時間乾燥した後の重量減は $1.01 \mathrm{wt} \%$ \%゙あった。この減量は, 試料に含まれている 溶媒に基くものであるから，表中， $300^{\circ} \mathrm{C}$ 以下の温度て は实質的に, ポリマーの重量減は認められない上考えら れる。

Table 1. Weight loss under molten state.

Sample: C, dried powder

Condition: Molten in $\mathrm{N}_{2}$ atmosphere

\begin{tabular}{cc|c|ccc}
\hline $\begin{array}{c}\text { Melting } \\
\text { temperature } \\
\left({ }^{\circ} \mathrm{C}\right)\end{array}$ & \multicolumn{5}{c}{ Melting time (min) } \\
\cline { 2 - 6 } & 10 & 20 & 40 & 80 & 160 \\
\hline 260 & $0.79^{*}$ & 0.67 & 0.80 & 0.91 & 0.87 \\
300 & 0.77 & 0.75 & 0.78 & 0.80 & 0.89 \\
340 & 0.94 & 0.88 & 0.97 & 1.33 & 1.86 \\
360 & 1.01 & 1.08 & 1.43 & 2.36 & 4.49 \\
\hline
\end{tabular}

* Unit : wt $\%$

Weight loss due to evaporation of solvent was 1.01 wt $\%$ when dried at $170^{\circ} \mathrm{C}, 10 \mathrm{hr}$.

\section{2 .2 低分子画分を除去した場合の分子量低下}

试料 A を Fig. 6 の方法で処理し，低分子画分の除 去程度の異なった試料 R 1〜R 4 について, 溶融を行な い, その分子量の変化を調べた。その結果を Table 2 に 示す。 


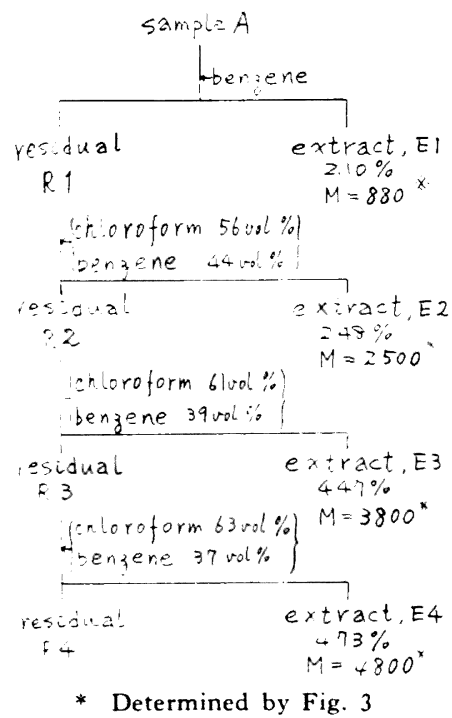

Sample : $100 \mathrm{~g}$, Solvent : $1000 \mathrm{cc}$,

Temperature : $23^{\circ} \mathrm{C}$, Time : $24 \mathrm{hr}$

Fig. 6. Procedure for eliminating low molecular weight fractions.

Table 2. Change in the molecular weight of polycarbonates cut off from low molecular

weight fractions under molten state.

Samples: Obtained from Fig. 6, dried powder

Condition: Molten at $300^{\circ} \mathrm{C}$, in $N_{\text {: }}$ atmosphere

\begin{tabular}{|c|c|c|c|c|c|c|}
\hline \multirow{2}{*}{$\begin{array}{c}\text { Sample } \\
\text { No. }\end{array}$} & \multicolumn{6}{|c|}{$\begin{array}{c}M W\left(\times 10^{4}\right) \text { after certain melting } \\
\text { duration (min) }\end{array}$} \\
\hline & 0 & 10 & 40 & 80 & 240 & 480 \\
\hline R 1 & 3.1 & - & 2.8 & 2.8 & 2.7 & 2.7 \\
\hline R 3 & 3.2 & 3.2 & 3.1 & 2.8 & - & - \\
\hline R 4 & 3.5 & 3.5 & 3.5 & 3.5 & - & - \\
\hline
\end{tabular}

この結果も Fig. 4 と同様, 分子量の低下には, ある 一定の限界值が琹められる。Fig. 4 との相違は低分子 を除去することによって，溶融による分子量の低下が非 行に少なくなっていることである。

\section{2 .3 低分子画分を添加した場合の分子量低下}

試料 A を Fig. 6 の方法で処理して, 種々な分子暴 の低分子画分 E 1 E 4 を得る。同時に得られる R 4 をバースとして, Table 3 のような割合で E 1 E 4 の 各低分子画分を均一添加して, RE 1 RE 4 なる試料お よびピスフェノール A を添加した RBPを得る。

これら陚料の溶融による分子量低下を Table 4 に示 した。いずれの試料とも，分子量の低下にはある一定值 が存在し, その限界值は, 添加した低分子画分の分子量
Table 3. Dose of the two components in various ratios.

Samples: Obtained from Fig. 6

Operation: Mixed in solution state

\begin{tabular}{|c|c|c|}
\hline Sample No. & Quantity of $\mathrm{R}$ and $\mathrm{E}$ & $\mathrm{E} \%$ \\
\hline RE 1 & $\mathrm{R} 4(32.64 \mathrm{~g})+\mathrm{E} 1(1.36 \mathrm{~g})$ & 4.0 \\
\hline RE 2 & $\mathrm{R} 4(31.28 \mathrm{~g})+\mathrm{E} 2(2.72 \mathrm{~g})$ & 8.0 \\
\hline RE 3 & $\mathrm{R} 4(28.56 \mathrm{~g})+\mathrm{E} 3(5.44 \mathrm{~g})$ & 16.0 \\
\hline RE 4 & $\mathrm{R} 4(27.84 \mathrm{~g})+\mathrm{E} 4(6.16 \mathrm{~g})$ & 18.1 \\
\hline RBP & $\mathrm{R} 4(29.70 \mathrm{~g})+\mathrm{BP}^{*}(0.30 \mathrm{~g})$ & 1.0 \\
\hline
\end{tabular}

* BP : bis-phenol-A

Table 4. Influence of a small addition of low molecular weight fractions on the change of molecular weight after melting.

Samples: Obtained from Table 3, dried powder

Condition: Molten at $300^{\circ} \mathrm{C}$ in $\mathrm{N}_{2}$ atmosphere

\begin{tabular}{c|c|c|c|c|c}
\hline Sample & \multicolumn{5}{|c}{$M W\left(\times 10^{4}\right) \begin{array}{c}\text { after certain melting } \\
\text { duration }(\mathrm{min})\end{array}$} \\
No. & 0 & 20 & 40 & 80 & 160 \\
\hline RE 1 & 3.1 & 2.6 & 2.5 & 2.2 & 2.2 \\
RE 2 & 3.0 & 2.7 & 2.5 & 2.5 & - \\
RE 3 & 3.0 & 2.8 & 2.8 & 2.7 & 2.7 \\
RE 4 & 3.1 & 3.0 & 3.0 & 3.0 & 2.7 \\
RBP & 3.1 & 2.2 & 2.0 & 1.8 & 1.7 \\
\hline
\end{tabular}

が低いほよ゙，添加量が少ないにもかかわらず，低い值を 示している。このことは分子量の低下が, 添加物のモル 数に比例して大きくなることを意味している。

\section{3 溶融による分子量分布の変化}

\section{3 .1 低分子側成分の変化}

2.4.1 の方法によって, R 1 R 4 および RE 1 RE 4, RBP の溶融による低分子側成分の変化を調べ，その 結果を Table 5, 6 にそれぞれ示した。

いずれの場合とも，分子壘の低下と低分子側成分の増 加とが平行的な関係にあり，低分子側成分の増加にも， ある一定の平衡值が認められる。

低分子画分を添加した場合，溶融によってそれらが減 少するという現象は恋められなかった。

低分子画分を抽出した残分の分子量は抽出前に比べて 3000 ５000 上昇した。

\section{3 .2 全分布の変化}

試料 $\mathrm{B}$ および $\mathrm{C}$ を乾燥し, 窒素気流中, $300^{\circ} \mathrm{C} て ゙$ 4 時間溶融したものと, 溶融しない重合粉末との分子量 分布を 2.4.2 の方法で测定し，その結果を Table 7 10 および Fig. 7〜10 に示した。ここで, $\int f(p) \cdot d p \times 10^{2}$ 
Table 5. Change in quantity of low molecular weight fraction after melting.

Samples: Same as Table 2

\begin{tabular}{c|cc|cc}
\hline \multirow{2}{*}{$\begin{array}{c}\text { Sample } \\
\text { No. }\end{array}$} & \multicolumn{3}{|c}{$\begin{array}{c}\text { Quantity* of low } \\
\text { certain melting duration (min) }\end{array}$} \\
\cline { 2 - 5 } & 0 & 10 & 40 & 80 \\
\hline R 1 & 96 & - & 103 & 107 \\
R 3 & 78 & 83 & 103 & 108 \\
R 4 & 84 & 87 & 81 & 113 \\
\hline
\end{tabular}

* Relative values (sample $A$ was standard) on total low molecular weight fractions which were extracted at $23^{\circ} \mathrm{C}$ successively by acetone, benzene and mixed solutions of chloroform and benzene (volumetric ratio $44: 56,42: 58,40: 60$ and $38: 62$ ).

Table 6. Change in quantity of low molecular weight fraction after melting.

Samples: Same as Table +

\begin{tabular}{crrrrr}
\hline \hline Sample & \multicolumn{6}{c}{$\begin{array}{c}\text { Quantity* of low } \\
\text { certain melting }\end{array}$ duration (min) } \\
No. & \multicolumn{1}{c}{0} & \multicolumn{1}{c}{20} & 40 & 80 & 160 \\
\hline RE 1 & 96 & 127 & 130 & 136 & 138 \\
RE 2 & 105 & 122 & 118 & 123 & 196 \\
RE 3 & 87 & 93 & 83 & 93 & 96 \\
RE 4 & 80 & 79 & 83 & 80 & 98 \\
RBP & 101 & 178 & 178 & 177 & 216 \\
\hline
\end{tabular}

* Relative values (sample A was standard) on total low molecular weight fractions which were extracted at $23^{\circ} \mathrm{C}$ successively by acetone, benzene and mixed solutions of benzene and chloroform (volumetric ratio $44: 56,42: 58,40: 60$ and $38: 62$ ).

は実測值から計算によって求められた積分分布関数で， $f(p) \times 10^{2}$ は，積分分布関数を常法により図上微分して 得られる微分分布関数である。

同じ方法で，溶融法(エステル突換法)によって得られ たポリマー(マクロロン)の分子量分有を測定した結果を Table 11 および Fig. 11 に示した。

これらの結果から, Schulz の方法 ${ }^{6}$ で，U 值(分子量 分布の不均一釈数) を求め,その結果を Table 12 に示 した。表中， $P_{\eta}$ は粘度法によって測定した重合度であ り， $P_{w}, P_{n}$ はそれぞれ重量平均重合度, 数平均重合度 である。 $P_{w}, P_{n}$ は皘分分布曲線から $\int f(p) \cdot d p \times 10^{2}$ が $5 \%$ に相当する重合度 $P_{1}, 15 \%$ ， に相当する重合度 $P_{2}, \ldots 85 \%$ に相当する重合度 $P_{9}, 95 \%$ に相当する重合 度 $P_{10}$ を読み取り, それぞれ重量平均, 数平均して求め た。得られた $P_{w}$ と $P_{n}$ の比を求めることによって, 分子量分布の幅を示す尺度とした。
Table 7. Data on the molecular weight distribution of sample $B$ by the successive extractive method.

\begin{tabular}{r|c|r|r|r}
\hline $\begin{array}{r}\text { Frac- } \\
\text { tion } \\
\text { No. }\end{array}$ & $\begin{array}{c}\text { Weight } \\
(\mathrm{g})\end{array}$ & $\begin{array}{c}\text { Weight } \\
\text { fraction } \\
(\%)\end{array}$ & $\begin{array}{c}\int^{\prime} f(p) \cdot \\
d p \times 10^{2}\end{array}$ & $\begin{array}{c}\text { Degree of } \\
\text { polymeri- } \\
\text { zation* }\end{array}$ \\
\hline 1 & 2.1198 & 4.11 & 2.05 & 18.1 \\
2 & 1.3558 & 2.62 & 5.42 & 40.6 \\
3 & 4.7489 & 9.20 & 11.33 & 64.6 \\
4 & 1.4169 & 2.74 & 17.30 & 68.2 \\
5 & 1.7642 & 3.42 & 20.38 & 71.7 \\
6 & 4.0051 & 7.77 & 25.97 & 92.5 \\
7 & 2.6736 & 5.18 & 32.45 & 100.3 \\
8 & 1.4510 & 2.82 & 36.45 & 104.4 \\
9 & 2.3915 & 4.64 & 40.18 & 107.5 \\
10 & 1.6267 & 3.15 & 44.07 & 117.3 \\
11 & 6.6087 & 12.80 & 52.05 & 122.9 \\
12 & 6.8773 & 13.32 & 65.11 & 136.0 \\
13 & 2.1797 & 4.22 & 73.88 & 137.9 \\
14 & 1.3871 & 2.69 & 77.33 & 147.0 \\
15 & 2.1492 & 4.17 & 80.76 & 152.0 \\
16 & 2.8409 & 5.50 & 85.60 & 165.9 \\
17 & 5.9790 & 11.65 & 94.17 & 180.8 \\
\hline & & & & \\
\hline
\end{tabular}

* Each values were calculated by deviding each molecular weight by repeating unit of polycarbonate $(=254)$.

Table 8. Data on the molecular weight distribution of sample B after melting.

Melting condition: Powder was dried and melted at $300^{\circ} \mathrm{C}, 4 \mathrm{hr}$ and in $\mathrm{N}_{2}$ atmosphere.

\begin{tabular}{ccr|rc}
$\begin{array}{c}\text { Frac- } \\
\text { tion } \\
\text { No. }\end{array}$ & $\begin{array}{c}\text { Weight } \\
(\mathrm{g})\end{array}$ & $\begin{array}{c}\text { Weight } \\
\text { fraction } \\
(\%)\end{array}$ & $\begin{array}{c}\int f(p) \cdot \\
d p \times 10^{2}\end{array}$ & $\begin{array}{c}\text { Degree of } \\
\text { polymeri- } \\
\text { zation }\end{array}$ \\
\hline 1 & 1.9957 & 3.98 & 1.99 & 17.3 \\
2 & 1.7385 & 3.47 & 5.71 & 35.4 \\
3 & 2.7192 & 5.42 & 10.36 & 48.0 \\
4 & 2.9216 & 5.84 & 15.79 & 66.5 \\
5 & 6.6700 & 13.30 & 25.36 & 78.4 \\
6 & 4.4578 & 8.80 & 36.41 & 81.1 \\
7 & 6.8172 & 13.60 & 47.61 & 90.6 \\
8 & 4.5133 & 9.02 & 58.92 & 96.1 \\
9 & 6.0078 & 12.00 & 69.43 & 99.2 \\
10 & 6.2540 & 12.50 & 81.68 & 106.8 \\
11 & 3.7502 & 7.48 & 91.67 & 116.5 \\
12 & 2.2835 & 4.59 & 97.70 & 142.1 \\
\hline
\end{tabular}

$U$ 做から見ると, 試料 B においては, 溶融によって あきらかに分子の大きさがそろったことを示している 
Table 9. Data on the molecular weight distribution of sample $\mathrm{C}$ by the successive extraction method.

\begin{tabular}{|c|c|c|c|c|}
\hline $\begin{array}{c}\text { Frac- } \\
\text { tion } \\
\text { No. }\end{array}$ & $\begin{array}{l}\text { Weight } \\
\text { (g) }\end{array}$ & $\begin{array}{c}\text { Weight } \\
\text { fraction } \\
\left(\begin{array}{l}0 \\
0\end{array}\right)\end{array}$ & $\int_{d p \times 10^{2}} f(p)$ & $\begin{array}{l}\text { Degree of } \\
\text { polymeri- } \\
\text { zation }\end{array}$ \\
\hline 1 & 2.2994 & 4.61 & 2.30 & 24.4 \\
\hline 2 & 2.3814 & 4.77 & 6.99 & 53.9 \\
\hline 3 & 3.0316 & 6.07 & 12.41 & 66.2 \\
\hline 4 & 3.9921 & 7.99 & 19.44 & 87.8 \\
\hline 5 & 4.3981 & 8.80 & 27.84 & 106.0 \\
\hline 6 & 6.8488 & 13.70 & 39.09 & 124.3 \\
\hline 7 & 6.3874 & 12.80 & 52.34 & 131.4 \\
\hline 8 & 3.3420 & 6.70 & 62.09 & 136.1 \\
\hline 9 & 8.5027 & 17.02 & 73.95 & 156.2 \\
\hline 10 & 1.1825 & 2.37 & 83.64 & 171.7 \\
\hline 11 & 1.4111 & 2.83 & 86.24 & 178.5 \\
\hline 12 & 6.1422 & 12.34 & 93.83 & 187.5 \\
\hline
\end{tabular}

Table 10. Data on the molecular weight distribution of sample $\mathrm{C}$ after melting.

Melting condition: Powder was dried and melted at $300^{\circ} \mathrm{C}, 4 \mathrm{hr}$, and in $\mathrm{N}_{2}$ atmosphere.

\begin{tabular}{rc|rrr}
\hline $\begin{array}{c}\text { Frac- } \\
\text { tion } \\
\text { No. }\end{array}$ & $\begin{array}{c}\text { Weight } \\
(\mathrm{g})\end{array}$ & $\begin{array}{c}\text { Weight } \\
\text { fraction } \\
(\%)\end{array}$ & $\begin{array}{c}\int f(p) \cdot \\
d p \times 10^{2}\end{array}$ & $\begin{array}{c}\text { Degree of } \\
\text { polymeri- } \\
\text { zation }\end{array}$ \\
\hline 1 & 1.8560 & 3.69 & 1.85 & 22.1 \\
2 & 3.0603 & 6.09 & 6.73 & 49.2 \\
3 & 3.2477 & 6.47 & 13.01 & 64.2 \\
4 & 2.3285 & 4.63 & 18.56 & 76.7 \\
5 & 4.3700 & 8.69 & 25.22 & 94.2 \\
6 & 2.6841 & 5.34 & 32.24 & 99.2 \\
7 & 1.7656 & 3.51 & 36.66 & 105.1 \\
8 & 5.3261 & 10.60 & 43.72 & 118.5 \\
9 & 6.1434 & 12.20 & 55.12 & 122.0 \\
10 & 3.5376 & 7.03 & 64.74 & 129.0 \\
11 & 2.2427 & 4.47 & 70.48 & 133.1 \\
12 & 3.6957 & 7.35 & 76.39 & 144.9 \\
13 & 4.0624 & 8.08 & 84.11 & 159.4 \\
14 & 5.9222 & 11.85 & 94.08 & 179.3 \\
\hline
\end{tabular}

が、圾籵Cに扔けては変化が見られなかった。いずれ の場台とも低分子側成分が, 溶融によって若干增加して いるのな鄙心られた。

\section{4. 考察}

4.1

氷点降下法と沸点上䄯法とによる測定結朵は非谠に上

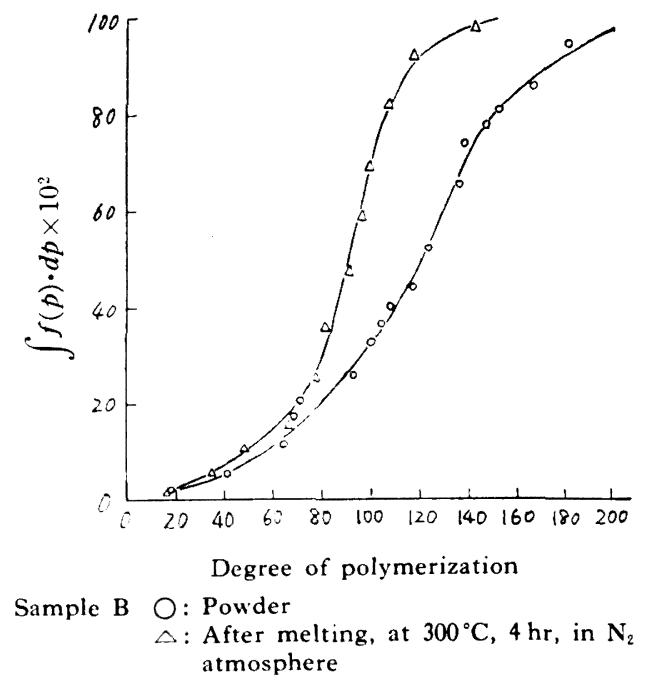

Fig. 7. Integral distribution curves by the successive extraction method.

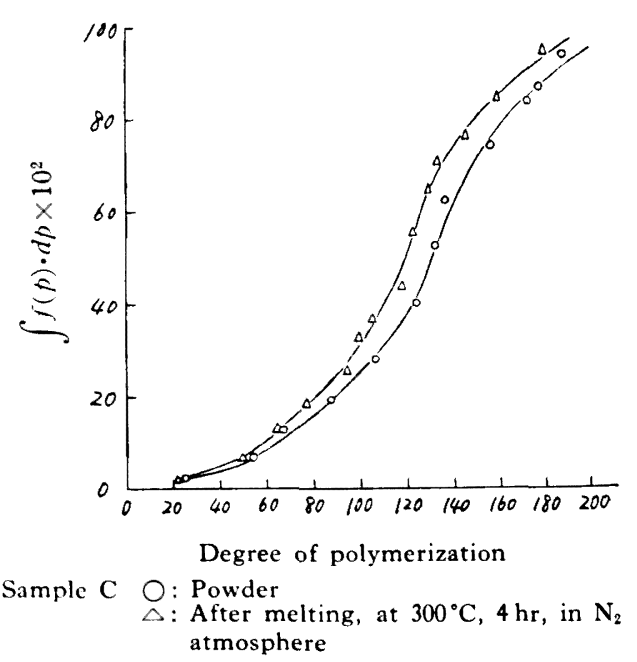

Fig. 8. Integral distribution curves by the successive extraction method.

く近似しているが，Schnel1 ${ }^{8)}$ の浸透圧法による結果と はかなりか汁離れている。この差は, Schnell の関係式 が，このような低分子筧箱囲を適用筑囲外としているこ

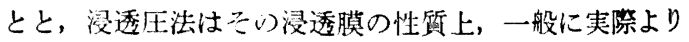
も高めの分子量を示すことによるものと考えられる。

\section{2}

$320^{\circ} \mathrm{C}$ 以下の溶融温度に才うて, ポリカーボネートの 分子量低下は，ある平衡值を有しており，それに達する 洔開は溶融温度に依存している。300 320 $\mathrm{C}$ において 若下のメチレンクロライド不溶分が生じるが，分子量の 


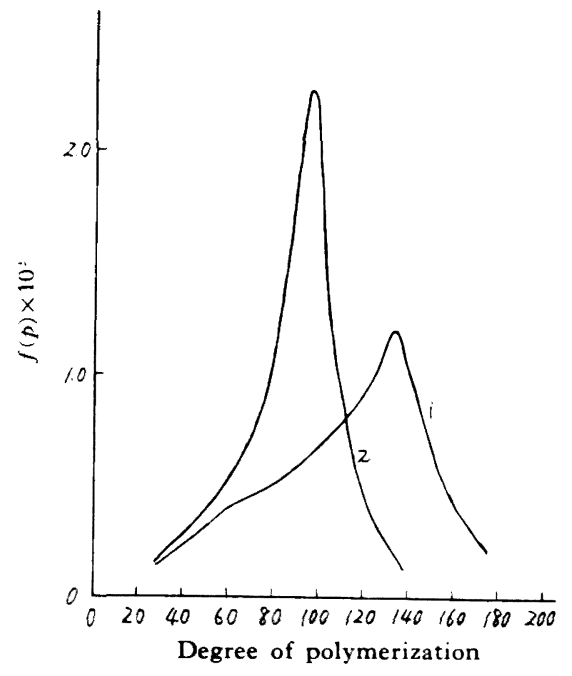

1: Powder

2: After melting, at $300^{\circ} \mathrm{C}, 4 \mathrm{hr}$, in $\mathrm{N}$ : atmosphere

Fig. 9. Molecular weight distribution curves of sample B.

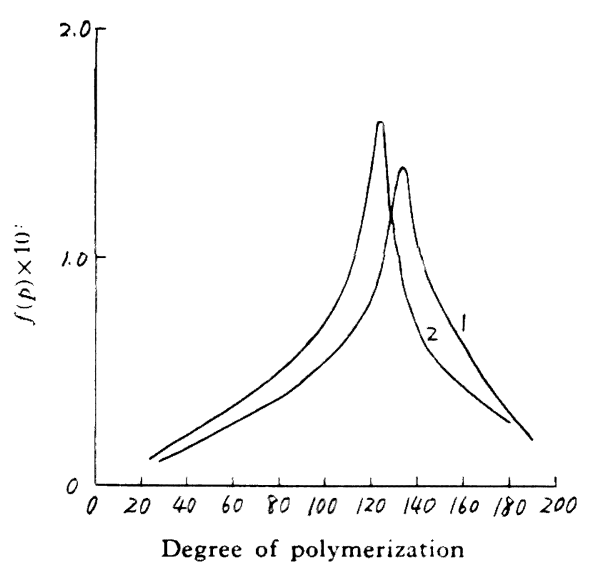

1: Powder

2: After melting, at $300^{\circ} \mathrm{C}, 4 \mathrm{hr}$ in $\mathrm{N}_{2}$ atmosphere

Fig. 10. Molecular weight distribution curves of sample $\mathrm{C}$.

低下には大きな影響がないと考えられる。

4.3

低分子画分を除去すると分子量低下は減少し, その程 度は低分子画分の除去程度に比例している。逆に低分子 画分を添加した場合は, そのモル数に比例して分子量低 下が増大する。これらの現象から，分子量の低下が分子 末端基に基いていることが推察される。

4.4

分子量の低下に伴って, 低分子側成分も増加するが,
Table 11. Data on the molecular weight distribution of Makrolon by the successive extraction method.

\begin{tabular}{rr|r|r|r}
\hline $\begin{array}{r}\text { Frac- } \\
\text { tion } \\
\text { No. }\end{array}$ & $\begin{array}{c}\text { Weight } \\
(\mathrm{g})\end{array}$ & $\begin{array}{c}\text { Weight } \\
\text { fraction } \\
\left(0^{\prime}\right)\end{array}$ & $\begin{array}{c}\int f(p) \cdot \\
d p \times 10^{2}\end{array}$ & $\begin{array}{c}\text { Degree of } \\
\text { polymeri- } \\
\text { zation }\end{array}$ \\
\hline 1 & 2.0177 & 4.04 & 2.02 & 15.4 \\
2 & 1.8901 & 3.79 & 5.93 & 31.5 \\
3 & 1.9400 & 3.89 & 9.77 & 38.6 \\
4 & 2.2129 & 4.43 & 13.93 & 46.4 \\
5 & 3.7233 & 7.46 & 19.88 & 54.7 \\
6 & 3.1607 & 6.34 & 26.78 & 62.6 \\
7 & 2.2283 & 4.47 & 32.18 & 68.9 \\
8 & 2.7943 & 5.60 & 37.22 & 77.9 \\
9 & 3.4274 & 6.87 & 43.45 & 87.1 \\
10 & 7.9982 & 16.02 & 54.90 & 117.0 \\
11 & 1.4527 & 2.92 & 64.37 & 124.0 \\
12 & 4.1659 & 8.35 & 70.00 & 146.0 \\
13 & 2.0563 & 4.12 & 76.24 & 156.7 \\
14 & 3.0771 & 6.16 & 81.38 & 180.5 \\
15 & 2.7888 & 5.59 & 87.25 & 195.0 \\
16 & 4.9544 & 9.95 & 95.02 & 208.2 \\
\hline & & & & \\
\hline
\end{tabular}

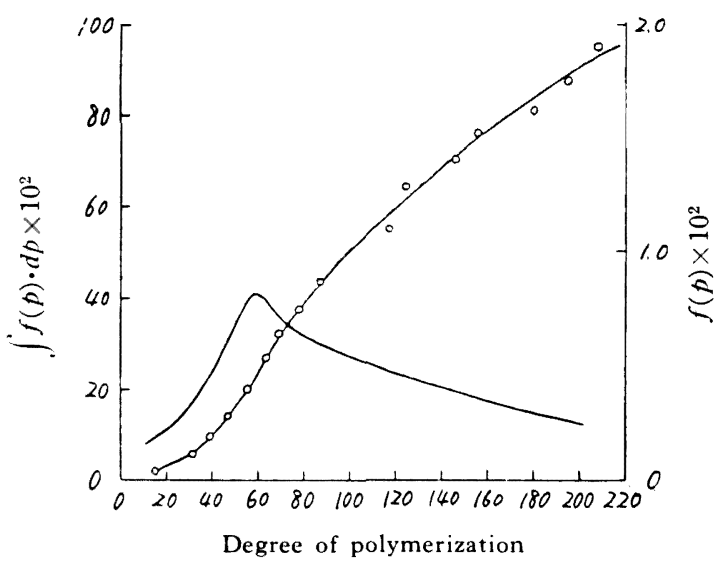

Fig. 11. Molecular weight distribution curves of Makloron.

その増加にも平衡值が現われる。また，分子量分布その ものは原試料によって鋭くなる場合と, ほとんど変化し ない場合とがある。この差は，原試料の低分子側成分の 多少, 未反応モ, マーの残存に基いていると考えられる。

\section{5}

ポリカーボネートの熱分解域以下の温度籁囲における 分子量の低下は, Flory の再配列理論7) で良く説明でき る。この現象は，ホスゲン化法によって得ら机たポリカ 
Table 12. The change in degree of polymerization and $U$-value after melting.

\begin{tabular}{l|r|r|r|r} 
& \multicolumn{3}{|c|}{ Sample } & \multicolumn{3}{|c|}{ Degree of polymerization } & \multirow{2}{*}{$U^{* * *}$} \\
& \multicolumn{1}{c|}{$P_{\eta}$} & \multicolumn{1}{|c|}{$P_{w}{ }^{*}$} & \multicolumn{1}{|c|}{$P_{n}{ }^{* *}$} & \\
\hline B (powder) & 113.3 & 116.8 & 93.8 & 0.24 \\
B (after melt) & 86.7 & 87.8 & 77.7 & 0.13 \\
C (powder) & 126.0 & 126.7 & 103.5 & 0.22 \\
C (after melt) & 115.3 & 116.0 & 95.4 & 0.22 \\
Makrolon & 103.4 & 110.1 & 76.1 & 0.45
\end{tabular}

* Calculated by $P_{w}=0.1 \sum_{i=1}^{10} P_{i}$

** Calculated by $P_{n}=10 / \sum_{i=1}^{10}\left(1 / P_{i}\right)$

*** $U=\left(P_{w} / P_{n}\right)-1$

一ボネートに多かれ少なかれ見られるもので，その程度 泣, 主として低分子側成分の多少に依存している。エス テル交換法によって得られたポリカーボネートは，すで に長時間, 溶融状態で処理されているため, この現象は ほ上んじ䜀められない。

4.6

Yakubovich2)も 4.2 に述べたと同様な現象を認めて いる。その報告によると, 再配列によって分子量分布は 鋭くなり, 低分子画分が著しく減少している。試料は分 子量 $6.2 \times 10^{4}$ で $1.0 \times 10^{4}$ 以下の成分が $20 \%$ も含ま
れていて, 分子量の低下は, 1 時間の溶融で $50 \%$ に達 している。われわれの使用した試料とあまりに相違して いるので，同一に比較はできないが，再配列によって分 子量分布が鋭くなるかどうか，また，その際低分子成分 が減少するか増加するかといら問題は, 原試料との相対 的な問題であろうと考える。たとえ代，反応過程ですで に再配列が達せられていると考えられるマクロロンの分 子量分布は，ホスゲン化法で得られたポリカーボネート よりも非常に広くなっており, しかも低分子側成分が非 常に多いものである。

付記：終りに本論文の発表を吘可された大潼常務に感即い たします。

\section{文献}

1) L. Placzek: Kunststoffe, 50, 174(1960); 可知博, 関口秀夫：高分子尌論会，(1960); 富川昌美： プ ラスチックス, 12, 13(1961); 富川昌美：高化, 20, 102(1963); Leing-huang Lee: “C \& EN, sept.”, $60(1962)$

2) A. Ya. Yakubovich: J. Polymer Sci., 55, 251 (1961)

3) H. Schnell : Angew. Chem., 68, 633(1956)

4) 鉄道技研：高分子学会第 10 回年次大会講演要旨 集

5) S. H. Merrill: J. Polymer Sci., 55, 343(1961)

6) G.V. Schulz: Zeitschrift für Elektrochemie, 60, 199(1956)

7) P. J. Flory: J. Am. Chem. Soc., 64, 2205(1942)

\title{
Studies on a Change in the Molecular Weight and Their Distribution of Molten Polycarbonates
}

\author{
By Takeshi Oe*, Hiroyuki Koda* and Hiroaki Yamazaki*
}

\begin{abstract}
Molecular weights and their distributions of polycarbonate, prepared by the phosgenation process, were measured after melting. When the polymer was melted at the temperature lower than $320^{\circ} \mathrm{C}$, the molecular weights decreased, showing some limiting values, and the shape of molecular weight distribution curves became somewhat sharper ones. The result could be explained as the influence of the amount of low molecular weight fractions.

The phenomenon of the Flory's "Random reorganization of molecular weight distribution", was observed.
\end{abstract}

